\title{
Status of arsenic toxicity in ground water in west bengal, india: a review
}

\begin{abstract}
Arsenic toxicity is a great threat in human civilization specially in West Bengal, India Almost half of the state is under the toxicity of this heavy metal. Several litho logical and stratigraphic studies revealed the stratigraphic position and the possibility of arsenic contamination in the lower gangetic delta region. A number of physiological anomalies in the human system such as Skin, respiratory, cardiovascular, Hematological disorder have been observed due to the chronic exposure to this. Apart from these disorders diabetes, genotoxic and cancer related complications have benn arised due to the exposure of arsenic. The present study revealed the present status of arsenic toxicity, stratigraphic condition of this state and the physiobiochemical consequence of chronic exposure of arsenic toxicity on human health.
\end{abstract}

Volume 3 Issue 5 - 2017

\author{
Rajsekhar Adhikary,' Vivekananda Mandal' \\ 'Department of Botany, University of Gour Banga, India \\ ${ }^{2}$ Department of Botany, University of Gour Banga, India
}

\begin{abstract}
Correspondence: Vivekananda Mandal, Ph. D, Professor Plant and Microbial Physiology and Biochemistry Laboratory, Department of Botany, University of Gour Banga, India, Tel +91 9679 008986, Fax 035 I 2223666, Email mandalvivek@gmail.com
\end{abstract}

Received: August 03, 2017 | Published: August 28, 2017

\section{Introduction}

The major source of freshwater in many parts of the world for meeting the requirements of daily purposes including agriculture is groundwater. The dependency on groundwater leads to approximately one-third of the world's population for drinking purposes. ${ }^{1}$ A large area of the world experiences a huge contamination in groundwater due to mixing of different toxic and minerals and heavy metals either naturally or unorganized development of human civilization. ${ }^{2,3}$ The Arsenic is one of the most important and fatal among these minerals. The high concentrations of arsenic (As) in drinking water in inorganic form causing skin, liver, lungs and other organs damages in several parts of the world. ${ }^{4}$ There are more than $25 \%$ of domestic wells presented in alluvial aquifers of this state carry arsenic in drinking water beyond the permissible limit of WHO, 1993, $2017(0.01 \mathrm{mg} / \mathrm{L})^{5,6}$ West Bengal lies within the Ganga-Brahmaputra delta basin has high contamination of arsenic $(<0.05 \mathrm{mg} / \mathrm{ml})$ mainly in groundwater. ${ }^{7}$ West Bengal can be divided into three arsenic prone zones ${ }^{8}$ i.e. highly affected areas cover eastern side of Bhagirathi River; mildly affected areas include northern part of the Bhagirathi river and the unaffected region carries western part of the state. This study reveals the condition of arsenic toxicity and stratigraphic and litho logical condition in West
Bengal, a state of India and the fatal effect on human health due to arsenic toxicity.

\section{Distribution of arsenic polluted area in west Bengal}

In India Arsenic contamination in ground water was first reported in West Bengal in $1978^{9}$ and it includes 79 blocks in 8 districts among 26 districts where arsenic concentration in ground water exceeded $50 \mu \mathrm{g} / \mathrm{L}$. According to Das, 2015, this problem is expanding rapidly and in 2006 almost 3235 villages were affected including North 24 Parganas, South 24 Parganas, Nadia, Murshidabad and Burdwan, Howrah, Hooghly and Maldah districts (Table 1). The severely affected districts are Murshidabad, Maldah, Nadia, North and South 24 Parganas, Burdwan, Howrah and Hooghly. The values of arsenic contaminated ground water of the affected districts are discussed below in Table 2. In course of this study, the numbers of affected blocks under the affected districts were too high. Almost all the district contains over $50 \%$ to $100 \%$ arsenic contaminated block. The condition of arsenic contamination in block level is discussed herewith in Table $3 .{ }^{9}$

Table I Progressive spread of arsenic contamination in West Bengal

\begin{tabular}{lllll}
\hline Date & No. of affected districts & No. of affected blocks & No. of villages & No. of affected municipalities \\
\hline MAY, 1993 & 7 & 34 & 78 & 3 \\
SEPT, 1995 & 7 & 56 & 388 & 9 \\
DEC, 1997 & 8 & 61 & 1302 & 9 \\
DEC, 1998 & 8 & 65 & 1312 & 9 \\
DEC, 1999 & 8 & 67 & 1550 & 11 \\
DEC, 2001 & 8 & 75 & 2065 & 11 \\
DEC, 2002 & 8 & 75 & 2579 & 11 \\
\hline
\end{tabular}


Table 2 Arsenic concentration in different districts of West Bengal up to 2006

\begin{tabular}{lll}
\hline Districts & $\begin{array}{l}\text { Permissible } \\
\text { limit (BSI) }\end{array}$ & $\begin{array}{l}\text { Arsenic concentration in } \\
\mathbf{m g} / \mathbf{L}\end{array}$ \\
\hline South 24 Parganas & & $0.06-3.20$ \\
North 24 Parganas & & $0.06-1.28$ \\
Maldah & & $0.05-1.434$ \\
Nadia & & $0.05-1.00$ \\
Murshidabad & $0.05 \mathrm{mg} / \mathrm{L}$ & $0.05-0.90$ \\
Burdwan & & $0.10-0.50$ \\
Howrah & & 0.09 \\
Hooghly & & 0.6 \\
\hline
\end{tabular}

Source: Planning commission of India (2007).

Table 3 No. of Arsenic affected blocks in different districts of West Benga in 2006

\begin{tabular}{lll}
\hline District & Total No. of blocks & No. of blocks affected \\
\hline MALDAH & 15 & 7 \\
MURSHIDABAD & 26 & 19 \\
NADIA & 17 & 17 \\
N.24 PARGANAS & 22 & 19 \\
S.24 PARGANAS & 29 & 9 \\
BURDWAN & 31 & 5 \\
\hline
\end{tabular}

\section{Stratigraphy and lithology of arsenic contaminated aquifers}

The stratigraphic analysis of arsenic prone aquifer zones of the southern part of West Bengal occurred beneath the alluvial plain. Soil thickness of the young delta plain (YDP) is $1-2 \mathrm{~m}$ thick with a top of soft $\mathrm{Fe}-\mathrm{Mn}$ concretions up to $0.2 \mathrm{~m}$, and lower section contains calcretes. In West Bengal, part of the Bengal basin of Bhagirathi, morpho stratigraphic units of the subsurface continuity have been established, ${ }^{10,11}$ whereas, lower subsurface units from YDP do not out cropped. The recognition of the quaternary section was difficult, but in many boreholes of western gangetic plains the sequence is mostly clay and sand. These have formed in saline water and contain microfossils locally to an Upper Pliocene age. ${ }^{12}$ The presence of the Toba-ash bed marker (75,000years b.p.) has been recorded to present in the basal parts of the quaternary profile of the Brahmani and Barakar River sections, slightly to the west of the Ganga-Brahmaputra basin margin. ${ }^{13}$ The arsenic-bearing aquifers are present in the Holocene sediments beneath YDP. Arsenic toxic YDP sediments partly encroached into the Barind area which is presented in north of Ganges channel, e.g. the Malda district of West Bengal. ${ }^{14}$ These Holocene valleys are filled with silt and clay which are deposited in deeply eroded and incised Barind sediments ${ }^{15}$ of Pleistocene age. Based on lithology revealed from drilling of groundwater and heavy mineral contents, the arsenic affected district of West Bengal have been classified into three stratigraphic zones broadly based on the subsurface sediments beneath the YDP of northern and southern West Bengal (Tables 4 \& 5). ${ }^{16-18}$

Table 4 Stratigraphic status of Raninagar, District Murshidabad,West Bengal, Inland region north. ${ }^{16}$

\begin{tabular}{llll}
\hline Unit & $\begin{array}{l}\text { Depth range } \\
(\mathbf{m}) \text { b.g.l. }\end{array}$ & Generalized lithology & $\begin{array}{l}\text { Range of arsenic in ground } \\
\text { water }(\mathbf{m g} / \mathbf{l})\end{array}$ \\
\hline $\begin{array}{l}\text { III (Not developed or condensed } \\
\text { section) }\end{array}$ & $0-6$ & Clay or sandy clay & $0.2-6.0$ \\
II & $6-50$ & $\begin{array}{l}\text { Fine to medium graineds and with clay } \\
\text { intercalations }\end{array}$ & $3.2-93.1$ \\
I & $40-70$ & Medium grained sand & $2.0-5.2$ (not sampled) \\
Disconformity Upper Tertiary & -10 & Silty clay & Not sampled \\
Average Arsenic content: Clay: I2ppm, sand: 4.8ppm & & \\
\hline
\end{tabular}

Table 5 Stratigraphic status of Ashoknagar, Halderbagan, District 24 parganas (north) West Bengal, Inland region central. ${ }^{16}$

\begin{tabular}{llll}
\hline Unit & Depth range $(\mathbf{m})$ b.g.l. & Generalized lithology & Range of arsenic in ground water $(\mathbf{m g} / \mathbf{l})$ \\
\hline III & $0-20$ & Clay & $0.1-6.2$ \\
& $20-55$ & Fine to medium grained sand with clay bands & $0.1-25.0$ \\
II & $55-70$ & Clay with fine grained sand & $2.0-15.0$ \\
& $70-115$ & Fine to medium grained sand with clay & $0.5-5.5$
\end{tabular}

Average Arsenic content: Clay: 9.5ppm, sand: 3.8ppm

\section{Effect of arsenic pollution in human health}

A prolonged and chronic exposure of arsenic in humans through drinking water, medications or occupational and environment affects multi organ system of human body (Figure 1). 


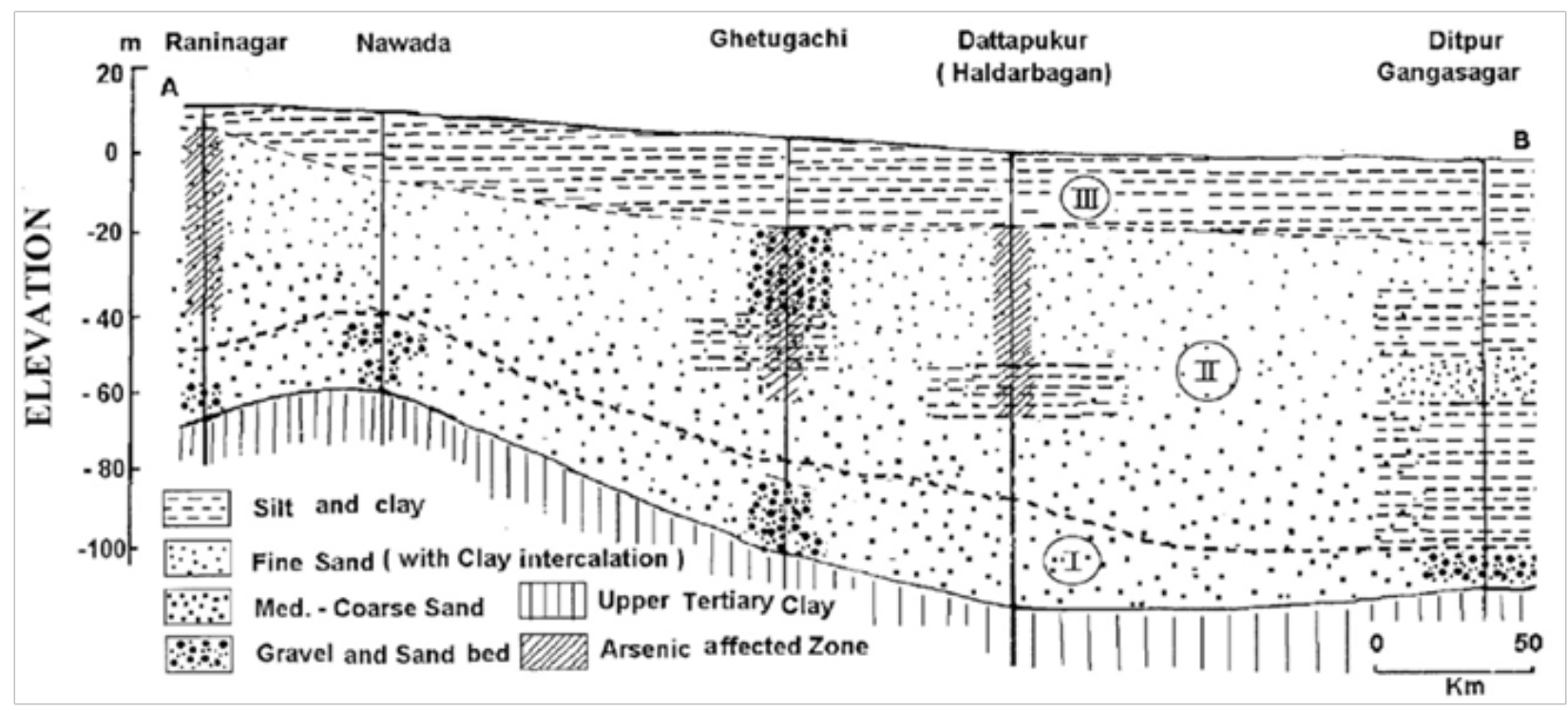

Figure I Stratigraphic and lithological organization of West Bengal. ${ }^{18}$

\section{Skin and systemic manifestations}

The specific skin diseases are pigmentation and keratosis, which are caused by chronic arsenic toxicity. The first population-based survey in West Bengal to assess the prevalence of keratosis and pigmentation was carried on 4,093 females and 3,590 males who were exposed to arsenic toxicity. ${ }^{19}$ The result revealed that men took the same exposure of arsenic through drinking water had two to three times more toxicity on both keratosis and pigmentation than the females. ${ }^{20}$ Chronic arsenic toxicity also produces various systemic manifestations over and above skin lesions in association with arsenical skin lesions. ${ }^{21}$

\section{Respiratory disease}

Non-malignant lung diseases are caused due to long exposure of arsenic contaminated drinking water $(800 \mathrm{mg} / \mathrm{L})$. About $38 \%$ of the arsenic exposed persons were experienced chronic cough, compared with $3.1 \%$ of the unexposed one. ${ }^{22}$ Chronic lung diseases were common in $57 \%$ of the exposure of chronic arsenic toxicity through arsenic contaminated drinking water in West Bengal. ${ }^{19}$

\section{Gastrointestinal disease}

Dyspepsia one of the most dominated (38.4\%) gastrointestinal syndrome for chronic arsenic toxicit. ${ }^{19}$ Gastroenteritis also caused by chronic arsenic sis through the drinking of arsenic-contaminated water with a concentration greater than $50 \mathrm{mg} / \mathrm{L} .{ }^{23}$

\section{Diseases of nervous system}

Peripheral neuropathy is caused by chronic exposure of arsenic through drinking water. ${ }^{23-28}$ Peripheral neuritis characterized by paresthesia (tingling, numbness, limb weakness, and others) was present in $47.4 \%$ of total patients of chronic arsenic sis in West Bengal, India. Several reports revealed that increased incidence of cerebrovascular disease in patients suffering from chronic arsenic sis. $^{23,27,29}$ There are also other neural complications such as peripheral neuritis, sleep disturbances, weakness, and cognitive and memory impairment also reported. ${ }^{20}$

\section{Cardiovascular disease}

The important complications of chronic arsenic toxicity is Blackfoot disease (BFD), a peripheral vascular disease. The prevalence of BFD has been reported as $8.9 \%$ of the affected people in arsenic. ${ }^{20}$ Another peripheral vascular disorder such as Raynaud's syndrome and acrocyanosis with varying degrees of severity have also been reported in West Bengal. Apart from that arsenic toxicity also increases around $6.2 \%$ of the prevalence of hypertension in West Bengal. $^{19}$

\section{Haematological effects}

Acute and chronic arsenic poisoning leads to anemia, leucopenia, and thrombocytopenia and other haematological abnormalities. ${ }^{30}$ West Bengal carries average 50\% anemia were caused in the exposure to arsenic-contaminated groundwater $(200-2,000 \mathrm{mg} / \mathrm{L})$.

\section{Diabetes}

Cumulative arsenic exposure and prevalence of diabetes mellitus were showed dose response relationship in arsenic endemic areas. ${ }^{32}$ In Bangladesh, diabetes mellitus prevalence also increased significantly where arsenic-contaminated water was taken as drinking water. ${ }^{33}$ There is no such report of diabetes mellitus caused by arsenic sis in West Bengal. ${ }^{20}$

\section{Arsenicosis and cancer}

Exposure to arsenic leads severe carcinogenicity in humans through drinking water. $^{34}$ This carcinogenicity is principally responsible in skin, urinary bladder, and lungs, among them $4.35 \%$ of skin cancer and $0.78 \%$ of internal cancers were detected in arsenicaffected villages In West Bengal through arsenic contamination. ${ }^{35}$

\section{Genotoxic effects}

A long-term exposure of arsenic through drinking water expresses genotoxic effects which includes increased rate of chromosomal aberrations and micronuclei formation in buccal and urothelial 
cells. $^{34,36,37}$ In West Bengal, the frequencies of formation of micronuclei were significantly high in peripheral lymphocytes, oral mucosa and urothelial cells and this effect is near 5-fold higher to exposed persons than unexposed ones. ${ }^{38}$

\section{Conclusion}

Chronic arsenic toxicity through the ingestion of arseniccontaminated groundwater makes a fatal hazard in human health throughout the world. Various skin, liver, cardiovascular, lungs, gastrointestinal disorders might become too much alarming in modern busy lifestyle. Different neurological anomalies and genotoxicity may lead to severe cause of genetic aberrations. ${ }^{39}$ The lithological and stratigraphic data revealed that the Ganga- Brahmaputra delta region is too much threatened because of the low thickness of lithological orientation. In this context, the key approach.

\section{Acknowledgements}

None.

\section{Conflict of interest}

The author declares no conflict of interest.

\section{References}

1. Anonymous UNEP. Conference of plenipotentiaries to adopt the protocol concerning pollution from land-based sources and activities to the convention for the protection and development of the marine environment of the wider Caribbean region. USA; 1999. p. 1-7.

2. Ravenscroft P, Brammer H, Richards KS. Arsenic Pollution: A Global Synthesis. USA: Blackwell-Wiley; 2009.

3. Onodera J, Takahashi K, Jordan RW. Eocene silicoflagellate and ebridian paleoceanography in the central Arctic Ocean. Paleoceanography. 2008;23(1):1-9.

4. Smith AH, Hopenhayn-Rich C, Bates MN, et al. Cancer risks from arsenic in drinking water. Environ Health Perspect. 1992;97:259-267.

5. Yu WH, Harvey CM, Harvey CF. Arsenic in groundwater in Bangladesh A geostatistical and epidemiological framework for evaluating health effects and potential remedies. Water Resour Res. 2003;39(6):1146.

6. Guidelines for Drinking water Quality. 4th ed. Switzerland: World Health Organisation (WHO); 2017. p. 1-564.

7. Mukherjee A, Fryar AE, Rowe HD. Regional-scale stable isotopic signatures of recharge and deep groundwater in the arsenic affected areas of West Bengal, India. Journal of Hydrology. 2008;334:151-161.

8. Sengupta MK, Hossain A, Ahamed S, et al. Groundwater arsenic contamination situation in West-Bengal, India:a nineteen-year study. BhuJal News. 2009;24:(2,3).

9. Das A. Ground Water Arsenic Contamination-A Study of Major Arsenic Affected Districts of West Bengal. Int J Sci Res. 2015;4(6):2993-2996.

10. Bhatacharya A, Banerjee SN. Quaternary geology and geomorphology of the Ajoy-Bhagirathi valley, Birbhum and Murshidabad districts, West Bengal. Indian J Earth Sci. 1979;2:51-61.

11. Niyogi D. Quaternary geology of the coastal plain in West Bengal and Orissa. Indian J Earth Sci. 1975;2:51-61.

12. Sengupta S. Geological and geophysical studies in western part of Bengal basin, India. Bull Am Assoc Petrol Geol. 1966;50(5):1001-1017.

13. Acharyya SK, Basu PK. Toba ash on the Indian subcontinent and its implication for correlation of late Pleistocene alluvium. Quat Res. $1993 ; 40: 10-19$
14. Monsur MH. An introduction to the Quaternary geology of Bangladesh. Bangaladesh: Rehana Akhter; 1995. $70 \mathrm{p}$.

15. Morgan JP, McIntire WC. Quaternary geology of the Bengal basin, East Pakistan and India. Bull Geol Soc Am. 1959;70(3):319-342.

16. Biswas AB, Roy RN. A study on the depositional processes and heavy mineral assemblage of the Quaternary sediments from Murshidabad district, West Bengal. Proc Indian Natl Sci Acad. 1976;42(5):372-386.

17. Deshmukh DS, Prasad KN, Niyogi BN, et al. Geology and groundwater resources of alluvial areas of West Bengal. Bull Geol Surv India Ser B. $1973 ; 34: 1-451$.

18. Acharyya SK, Lahiri S, Raymahashay BC, et al. Arsenic toxicity of groundwater in parts of the Bengal basin in India and Bangladesh: the role of Quaternary stratigraphy and Holocene sea-level fluctuation. Environmental Geology. 1999;39(10):1127-1137.

19. Guha Mazumder DN, Haque R, Ghosh N, et al. Arsenic levels in drinking water and the prevalence of skin lesions in West Bengal, India. Int J Epidemiol. 1998;27(5):871-877.

20. Guha Mazumder D, Dasgupta UB. Chronic arsenic toxicity: Studies in West Bengal, India. Kaohsiung Journal of Medical Sciences. 2011;27(9):360-370.

21. Majumder KK, Guha Mazumder DN, Ghose N, et al. Systemic manifestations in chronic arsenic toxicity in absence of skin lesions in West Bengal. Indian J Med Res. 2009;129(1):75-82.

22. Borgono JM, Vicent P, Venturino H, et al. Arsenic in the drinking water of the city of Antofagasta: epidemiological and clinical study before and after the installation of a treatment plant. Environ Health Perspect. 1977;19:103-105.

23. Ma HZ, Xia YJ, Wu KG, et al. Human exposure to arsenic and health effects in Bayingnormen, Inner Mongolia. In: Chappell WR, Abernathy $\mathrm{CO}$, editors. Arsenic exposure and health effects. The Netherlands; 1999. p. 127-131.

24. Ahmad SA, Sayed MHSU, Hadi SA, et al. Arsenicosis in a village in Bangladesh. Int J Environ Health Res. 1999;9(3):187-195.

25. Cebrian ME, Albores A, Aguilar M, et al. Chronic arsenic poisoning in the north of Mexico. Hum Toxicol. 1983;2(1):121-133.

26. Saha KC. Melanokeratosis from arsenic contaminated tube well water. Indian J Dermatol. 1984;29(4):37-46.

27. Hotta N. Clinical aspects of chronic arsenic poisoning due to environmental and occupational pollution in and around a small refining spot. Nippon Taishitsugaku Zasshi. 1989;53:49-70.

28. Kilburn KH. Neurobehavioral impairment from long-term residential arsenic exposure. In: Abernathy CO, Calderon RL, editors. Arsenic exposure and health effects. UK; 1997. p. 159-177.

29. Chen CJ, Chiou HY, Huang WI, et al. Systemic non-carcinogenic effects and developmental toxicity of inorganic arsenic. In: Abernathy $\mathrm{CO}$, Calderon RL, editors. Arsenic exposure and health effects. UK; 1997. p. 124-134.

30. Arsenic in drinking water. USA: NRC (National Research Council), National Academic Press; 1999. p. 27-82.

31. Guha Mazumder DN, Chakraborty AK, Ghosh A, et al. Chronic arsenic toxicity from drinking tube-well water in rural West Bengal. Bull World Health Organ. 1988;66(4):499-506.

32. Lai MS, Hsueh YM, Chen CJ, et al. Ingested inorganic arsenic and prevalence of diabetes mellitus. Am J Epidemiol. 1994;(13995):484-492.

33. Rahman M, Tondel M, Ahmad SA, et al. Diabetes mellitus associated with arsenic exposure in Bangladesh. Am $\mathrm{J}$ Epidemiol. 1998;(14892):198-203. 
34. Some drinking-water disinfectants and contaminants, including arsenic IARC Monogr Eval Carcinog Risks Hum. 2004;84:1-477.

35. Saha KC. Saha's grading of arsenicosis progression and treatment. In: Chappell WR, Abernathy CO, editors. Arsenic exposure and health effects. Oxford, UK; 2003. p. 391-414.

36. Warner ML, Moor LE, Smith MT, et al. Increased micronuclei in exfoliated bladder cells of individuals who chronically ingest arsenic contaminated water in Nevada. Cancer Epidemiol Biomarkers Prev. 1994;3(7):583-590.
37. Gonsebatt ME, Vega L, Salazar AM, et al. Cytogenetic effects in human exposure to arsenic. Mutat Res. 1997;386(3):219-228.

38. Basu A, Ghosh P, Das JK, et al. Micronuclei as biomarkers of carcinogen exposure in populations exposed to arsenic through drinking water in West Bengal, India:a comparative study in 3 cell types. Cancer Epidemiol Biomarkers Prev. 2004;13(5):820-827.

39. Guha Mazumder DN. Criteria for case definition of arsenicosis. In: Chappell WR, Abernathy CO, editors. Arsenic exposure and health effects. Oxford, UK; 2003. p. 117-135. 